Universitas Muhammadiyah Bengkulu P-ISSN: 2599-1892

Vol. 1, No. 1, Januari 2018

\title{
Tanggung Jawab Sosial Perusahaan Yang Dilakukan oleh Perseroan Terbatas Perkebunan Nusantara VII di Kecamatan Sukaraja Kabupaen Seluma
}

\section{Corporate Social Responsibility Carried Out by Nusantara VII Plantation Limited Company in Sukaraja District Seluma Regency}

\section{Tri Murni Pujianti}

Universitas Muhammadiyah Bengkulu, email: tri.mp90@gmail.com

\begin{abstract}
ABSTRAK
PT.Perkebunan Nusantara VII (Persero) kecamatan sukaraja kabupaten seluma merupakan salah satu Badan Usaha Milik Negara (BUMN) Perkebunan. PTPN III menyadari kewajiban program Corporate Social Responsibility (CSR) yang merupakan Tanggung Jawab Sosial Perusahaan sebagai upaya untuk mewujudkan kesejahteraan dan kemakmuran masyarakat serta kelestarian fungsi lingkungan hidup. Karena itu diperlukan hubungan sinergis antara pemerintah, para pelaku usaha dan masyarakat. Untuk merealisasikan Tanggung Jawab Sosial Perusahaan tersebut maka PT. Perkebunan Nusantara VII (Persero) menerapkan program CSR yaitu salah satu nya Program kemitraan, kedermawanan, pembangunan, keagamaan pelestarian lingkungan dan lain-lain yang menjadi salah satu cara perusahaan untuk menaikkan citra perusahaan dan akan menjadi nilai tambah atau suatu keunggulan perusahaan dalam menghadapi persaingan dalam dunia industri. Metode penelitian ini adalah penelitian hukum empiris. Hasil penelitian menunjukan bahwa program tanggung jawab sosial perusahaan belum terlaksana secara efektif terutama dibidang kesehatan (Perusahaan membuang limbah disungai Andalas), dibidang pendidikan (Perusahaan tidak memberikan beasiswa), dibidang lingkungan ( Jalan yang rusak).
\end{abstract}

\section{Kata kunci: Tanggung Jawab Sosial, PTPN VII}

\begin{abstract}
Nusantara VII Plantation Limited Company of Sukaraja District Seluma Regency is one of the Plantation State-Owned Enterprises (SOES). PTPN III recognizes the obligation of Corporate Social Responsibility (CSR) program which is Social Responsibility of the Corporation as an effort to realize the society's prosperity and welfare and the preservation of environmental function. Therefore, a synergic relationship between the government, business actors and the community is needed. To realize the Social Responsibility of the Corporation, Nusantara VII Plantation Limited Company implements CSR program such as partnership program, philanthropy, development, religious,
\end{abstract}


preservation of the environment and others that become one of the company's ways to raise the company image and will be an added value or a corporate advantage in facing the competition in industry world. This research method is empirical legal research. The results showed that the corporate social responsibility program has not been implemented effectively, especially in the field of health (the Company disposes its waste into Andalas River), in the field of education (the Company does not provide scholarships), and in the field of environment (the Roads are damaged).

\section{Keywords: Social Responsibility, PTPN VII}

\section{PENDAHULUAN}

Perusahaan sebagai sebuah identitas badan hukum memiliki perusahaan (Coorporate SocialResponsibility/CSR). Dalam praktiknya selama ini masih terdapat beberapa perusahaan yang melaksanakan programtanggung jawab sosial perusahaan CSR hanya bersipat sukarela (Voluntary) yang tidak memiliki komitmen berkelanjutan. CSR hanya dilakukan $\pm 30 \%$ dari keseluruhan perusahaan yang beroperasi diIndonesia, dan kegiatannya sendiri lebih terfokus pada kedermawanan (philanthropy) dan kemurahan hati(charity) dalam rangka membantu korban bencana alam.

Terkhusus untuk di Perusahaan Perseroan Terbatas Perkebunan nusantara VII di kabupaten Seluma yang juga merupakan Badan Usaha Milik Negara Indonesia yang bergerak di bidang perkebunan karet, Perusahaan ini berkantor pusat di Kecamatan Sukaraja Kabupaten Seluma, dengan wilayah operasi meliputi kawasan bengkulu .

Kepedulian perusahaan sebagai bagian dari tanggungjawab sosial perusahaan atau CSR terwujuddalam komitmen perusahaan untuk mempertanggungjawabkan dampakdampak dari kegiatan usahayang dijalankannya dalam aspek ekonomi, sosial dan lingkungan yang sejalan dengan konsep Triple Bottom Line, apabila terjadi sangketa dalam program TSP , penyelesaian nya dilakukan secara musyawara mufakat dan apabila tidak dicapainya penyelesaian maka dapat dilakukan dengan cara Non Litigasi (diluar pengadilan), namun apabila tidak dilaksanakannya program TSP ini maka akan dikenakan sanksi administratif seperti peringatan tertulis, pembatasan kegiatan usaha, pembekuan kegiatan usaha atau fasilitas serta mencabut 
kegiatan usaha atau fasilitas penanaman modal. ${ }^{1}$

Dalam Undang-Undang Nomor 40 Tahun 2007 tentang Perseroan Terbatas yaitu pada Pasal 74 ayat (1) m enyebutkan bahwa perseroan yang menjalankan kegiatan usahanya dibidang dan berkaitan dengan sumber daya alam wajib melaksanakan tanggung jawab sosial dan lingkungan. ${ }^{2}$ Seharusnya dari pihak Perseroan Terbatas Perkebunan Nusantara VII dapat melaksanakan program TSP (Tanggung JawabSosial Perusahaan)secara baik oleh masyarakat sekitar sebagai contoh bina lingkungan ,Kemitraan Usaha Mikro kecil,ataupun program langsung pada masyarakat sebagai usaha pengembangan perusahaan dalam jangka yang cukup panjang. dengan keadaan serupa Perseroan Terbatas perkebunan nusantara VII telah merealisasikan program TSP nya secara berimbang dengan penyaluran pembantuan atas pemberdayaan lingkungan, memberi bantuan secara langsung dari pihak karang taruna, berpartisipasi dalam setiap agenda

\footnotetext{
${ }^{1}$ Pasal 19, 20 undang-undang No 1 tahun 2014 tentang Penyelesaian sangketa dan Sanksi Admistratif

${ }^{2}$ Pasal 74 ayat(1) Undang-undang No.40 tahun 2007 tentang Tanggung jawab Sosial dan lingkungannya
}

tahunan, memberi bantuan kedermawanan dan masih banyak lagi namun dari keadaan penulis mengangkat judul proposal ini tentang tanggung jawab sosial perusahaan di PTPN VII, penulis ingin mengetahui apakah dari tanggung jawab sosial yang dilakukan oleh pihak perseroan terbatas perkebunan nusantara VII merupakan program yang sipatnya berkelanjutan (dapat diteruskan) atau sekedar Voluntar ( suka rela) saja.

Oleh karena itu penulis sangat tertarik untuk mengangkat sebuah judul tentang Tanggung Jawab Sosial Perusahaan yang dilakukan oleh Perusahaan Perseroan Terbatas Perkebunan Nusantara VII di Kabupaten Seluma,yang menitik berat pada implementasi lapangan terhadap masyarakat disekitarnya apakah telah dilaksanakannya program Corporate Social Responsibily secara baik dan benar, memiliki komitmen prusahaan yang berkelanjutan atau hanya sekedar Volutary (suka Rela) sesuai dengan Undang-undang No 40 tahun 2007 tentang Perseroan Terbatas, Perat uran daerah ( Perda) No 1 tahun2014.

Bertitik tolak dari hal tersebut di atas, maka yang menjadi permasalahan dalampenelitian ini adalah : 
Tanggung Jawab Sosial Perusahaan yang Dilakukan oleh PTPN VII

Di Kecamatan Sukaraja Kabupaten Seluma

1. Bagaimana prosedur dan model Pelaksanaan Tanggung Jawab Sosial yang dilakukan oleh perusahaan PTPN VII di kebupaten seluma?

2. Bagaimana bentuk sanksi yang diberikan apabila tanggung jawab sosial perusahan PTPN VII Kabupaten seluma tidak dilaksanakan?

\section{METODE PENELITIAN}

Dalam penelitian hukum yang dilakukan oleh penulis adalah dengan menggunakan metode penelitian hukum Sosiologis/empiris.Data primer diperoleh dari penelitian lapangan ${ }^{3}$ yaitu Perusahaan Perseroan Terbatas Perkebunan Nusantara VII di kecamatan sukaraja , Kabupaten Seluma sedangkan data skundernya penulis memperoleh dari Kepustakaan, seperti buku-buku, jurnal, Peraturan perudang-undangan, peraturan Pemerintah, peraturan daerah ataupun yang lainnya.

wilayah generalisasi yang terdiri atas obyek/subyek yang mempunyai kualitas dan karakteristik tertentu yang ditetapkan oleh peneliti untuk dipelajari dan ditarik kesimpulannya (pelaksanaan Tanggung Jawab Sosial Perusahaan di Perseroan

\footnotetext{
${ }^{3}$ Serjono Soekanto,2005. Pengantar Penelitian Hukum ,Universitas Indonesia ,Jakarta:Raja

Terbatas Perkebunan Nusantara VII/ PTPN Unit Usaha Padang Pelawi) terhadap pihak perusahaan, baik tenaga kerja atau bagiannya,yang (di lihat dari segi Lingkungan perusahaan, Pendidikan, Sosial, Kesehatan, olahraga, kemitraan, agama, dan sebagainya sebagai tanggung jawab sosial yang wajib dilakuka. ${ }^{4}$

Data Yang Dicari ( Data yang dikumpulkan dalam tahap penelitian ini adalah data yang didapat dari pihak Perseroan Terbatas Perkebunan Nusantara VII padang pelawi dalam proses Tanggung Jawab Sosial Perusahaan. Serta melakukan obserpasi terhadat masyarakat disekitar perusahaan apakah sesuai dengan peraturan peraturan yang telah dibuat) .

a). Data berupa Das Sollen yakni sebagai segala sesuatu yang seharusnya terjadi atau sesuatu yang berdasarkan teori dan berdasarkan aturan seharusnya terjadi, seperti peraturan-peraturan tentang tanggung jawab sosial perusahaan yang dilakukan untuk masyarakat sekitar perusahaan.

b). Data berupa Das Sein yakni data yang merupakan pelaksanaan dari segala sesuatu yang diatur dalam

\footnotetext{
${ }^{4}$ Sugiyono.2014.Metode Penelitian Kuantitatif Kualitatif dan R\&D. Bandung:Alfabeta, halaman 215
} 
das sollen. Atau dengan kata lain das solen adalah apa yang terjadi dari pelaksanaan das solen.Seperti data yang sesuai dengan keadaan lapangan yang berkaitan apakah bersinambung dengan peraturanperaturan tentang tanggung jawab sosial perusahaan kepada masyarakat disekitarnya.

Pengolahan data dilakukan dalam beberapa tahapan.Tahap pertama pengolahan data dimulai dari penelitian pendahuluan hingga tersusunnya usulan penelitian. Tahap kedua, pengolahan data yang lebih mendalam dilakukan dengan cara mengolah hasil kegiatan wawancara dan pengumpulan berbagai informasi lapangan di lokasi penelitian. Tahap ketiga, setelah itu dilakukan pemeriksaan keabsahan data hasil wawancara dengan sejumlah nara sumber yang dijadikan informasi penelitian serta membandingkan data tersebut dengan berbagai informasi yang terkait. membandingkan antara obserpasi di PTPN dengan masyarakat lingkungan perusahaan. Pada tahap ini, pengolahan data dianggap optimal apabila data yang diperoleh sudah layak dianggap lengkap dan dapat merepresentasikan masalah yang dijadikan obyek penelitian.Tahap akhir adalah analisis data dalam rangka menjawab pertanyaan- pertanyaan penelitian yang dilakukan dengan pendekatan analisis triangulasi.Sehingga pada tahap analisis data ini penulis menggunakan analisis data yang bersipat. Data Kualitatif adalah data yang dinyatakan dalam bentuk kata-kata, kalimat dan gambar. Dalam penelitian ini yang merupakan data kualitatif adalah gambaran umum yang ditarik kesimpulannya yang

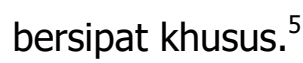

\section{PEMBAHASAN}

Prosedur dan Model Pelaksanaan

Tanggung Jawab Sosial yang dilakukan oleh Perusahaan PTPN VII di kecamatan Sukaraja kebupaten

\section{Seluma}

Implementasi tanggung jawab sosial perusahaan yang memiliki efektivitas yang tinggi hanya dapat dicapai jika pelaku usaha tidak lagi berperan hanya sebagai dermawan. Sikap tersebut hanya akan berdampak negatif, yaitu melestarikan ketergantungan pada uang kontribusi. Pelaksanaan tanggung jawab sosial perusahaan, semestinya dapat dibangun suatu relasi dalam bentuk mitra kerja antara perusahaan dengan masyarakat setempat dalam upaya mencapai tujuan

\footnotetext{
" "Metode Penelitian",melalui http://www.MetodePenelitian.com, diakses tanggal 13 maret 2015 Pukul 13.20
} 
Tanggung Jawab Sosial Perusahaan yang Dilakukan oleh PTPN VII

Di Kecamatan Sukaraja Kabupaten Seluma

bersama. ( Tanggung Jawab Sosial Perusahaan) meliputi:

1. Bantuan Pembiayaan Penyelenggara kesejahteraan sosial

2. Konpensasi dan

3. Peningkatan fungsi lingkungan hidup serta memacu pertumbuhan ekonomi berkualitas berbasis kerakyatan yang selaras dengan program-program pemerintah daerah.

Sedangkan untuk Program-program Pemerintah Daerah tentang Tanggung Jawab Sosial Perusahaan (TSP) yang dibebankan pada Perseroan Terbatas ( PT ) meliputí:

1. Bina Lingkungan dan Sosial

2. Kemitraan Usaha Mikro Kecil, dan Koperasi serta

3. . Program Langsung pada masyarakat.

Untuk melaksanaan Tanggung Jawab Sosial Perusahaan (TSP), Perusahaan wajib menyusun, menata, merancang dan melaksanakan kegiatan TSP sesuai dengan prinsip-prinsip tanggung jawab sosial dunia usaha dengan memperhatikan kebijakan pemerintah daerah dan peraturan perundang-undangan yang berlaku. Menumbuhkan, memantapkan dan mengembangkan sistem jejaring

\footnotetext{
${ }^{6}$ Pasal 11 ayat 1 Peraturan Daerah Nomor 1 tahun 2014 tentang Program TSP
}

kerjasama dan kemitraan dengan pihakpihak lain serta melaksanakan kajian, monitoring dan Evaluasi terhadap pelaksanaan Tanggung Jawab Sosial Perusahaan (TSP) dengan memperhatikan kepentingan perusahaan, masyarakat, pemerintah daerah serta kelestarian lingkungan menetapkan bahawa Tanggung Jawab Sosial Perusahaan bagian yang tak terpisahkan dalam kebijakan manajemen maupun program pembangunan perusahaan. ${ }^{7}$

Penyelenggaraan kesejahteraan sosial, konpensasi dan peningkatan fungsi lingkungan hidup memacu pertumbuhan ekonomi berkualitas berbasis kerakyatan sebagaimana dimaksud dalam pasal 6 ayat (1) dialokasikan dari sebagian keuntungan bersih setelah pajak atau dialokasikan dari mata anggaran lain yang ditentukan perusahaan. ${ }^{8}$

Sehingga dari sini lah penulis menjabarkan tentang fakta-fakta yang terjadi dilapangan. Tepatnya pada perusahaan Perseroan Terbatas Perkebunan Nusantara VII Unit Usaha Padng Pelawi .

\footnotetext{
${ }^{7}$ Pasal 10 (a,b,c) Peraturan daerah nomor 1 tahun 2014 tentang pelaksanaan Tanggung Jawab Sosial Perusahaan.

${ }^{8}$ Pasal 7 ayat (1) Peraturan Daerah nomor 1 tahun 2014 tentang pembiayaan.
} 
Tercatat tanggung jawab yang dilakukan oleh PT perkebunan karet tersebut meliputi ${ }^{9}$ dari segi Kemitraan, Kedermawanan, Pendidikan, Kesehatan, Pembangunan, Keagamaan, dan Pelestarian Lingkungan.

Berikut ini diuraikan program dan pelaksanaan Tanggung Jawab Sosial Perusahaan sebagai berikut:

\section{a). Dari Segi Kemitraan.}

PT perkebunan karet di unit usaha padang pelawi telah melaksanakan program Kemitraan bina lingkungan dengan memberikan bantuan modal kepada masyarakat disekeliling perusahaan. Dengan adanya pendataaan yang akurat, masyarakat sekitar perusahaan dapat melaksanakan program tersebut secara baik dan berdaya guna sekaligus dapat melakukan pengembangan mitra binaan.

\section{b). Dari Segi Kedermawanan}

Dari hasil pelaksanaanya dilapangan terlihat bahwa program yang menyangkut masalah kesehatan atau bantuan untuk orang-orang sakit dikhususkan untuk target groupnya

\footnotetext{
${ }^{9}$ Wawancara Bagian CSR/ Tanggung jawab sosial perusahaan.dianto kausel.pada tanggal 14 april 2015.pukul 09.00

Wawancara bagian Umum PTPN VII Unit Usaha Padang Pelawi.Ratimi.tanggal 15april2015.pukul 10.00
}

atau untuk karyawan-karyawan, stafstaf perkebunan karet (Persero) bukan di berikan kepada masyarakat diluar perusahaan melainkan hanya untuk karyawan-karyawan Perkebunan karet (persero) unit usaha padang pelawi. Seperti tidak di dirikannya klinik pengobatan/ puskesmas bebas untuk masyarakat di luar perusahaan namun hanya terdapat di dalam lingkungan perusahaan saja disebut (PUSKESBUN) itu pun dikhususkan hanya untuk karyawan-karyawan, Staf- staf, kuli PT Perkebunan Karet (persero) baik dari karyawan bulanan, teknik, pabrik, dan sadapan.

\section{c). Dari Segi Pendidikan}

Dari hasil pelaksanaanya dilapangan terlihat bahwa program yang dilakukan dari segi pendidikan dibidang pemberian beasiswa hanya dikhususkan kepada anak-anak yang berprestasi pada lingkup perusahaan nya saja baik untuk anak pekerja golongan IA s/d ID ( mendapatkan ranking/Juara 1 dan 2), ditingkat SD ( kelas $1 \mathrm{~s} / \mathrm{d}$ 5), ditingkat SLTP (kelas 1 dan 2), ditingkat SLTA (kelas 1 dan 2) dengan menyerahkan Fotocopy rapot terakhir yang telah dilegalisir, melampirkan data-data anak seperti ( nama ayah, golongan ayah, 
Tanggung Jawab Sosial Perusahaan yang Dilakukan oleh PTPN VII

Di Kecamatan Sukaraja Kabupaten Seluma

afdeling/bagian, nama anak, nama sekolah, keterangan rangking/ juara). program beasiswa tersebut hanya diberikan terkhusus untuk anak -anak karyawan, bukan untuk anak-anak diluar target grup PTPN unit usaha padang pelawi. Keadaan yang terjadi membuat masyarakat merasa tidak diberikannya hak akan tanggung jawab sosial perusahaan unit usaha padang pelawi dari segi pendidikan.

\section{d). Dari Segi Kesehatan}

Dari hasil pelaksanaanya dilapangan terlihat bahwa program yang dilakukan dari segi kesehatan sudah cukup baik untuk lingkup group perusahaan, namun untuk segi masyarakat sekitar perusahaan yang masih sangat perlu diperhatikan dikarenakan banyak pencemaran yang terjadi sehingga memberikan dampak negatif yang dirasakan masyarakat sekitar perusahaan seperti pembuangan limbah pabrik yang berhulu pada air sungai andalas, pencemaran sungai jenggalu yang digunakan sebagai air PDAM kota Bengkulu, karena pada awalnya sungai tersebut digunakan sebagai bahan pokok kehidupan masyarakat sekitar perusahaan, digunakan untuk mandi, air minum pada saat kemarau dan sebagainya. Namun sekarang mandi saja masyarakat merasa takut apalagi digunakan untuk bahan makanan dan minuman sehari-hari.

\section{e). Dari Segi Pembangunan}

Dari hasil pelaksanaan dilapangan terlihat bahwa program yang dilakukan dari segi pembangunan cukup baik atau memiliki kewajiban akan Tanggung Jawab Sosial Perusahaan yang memang harus dilaksanakan oleh perusahaan namun ada satu hal yang sangat memprihatinkan yaitu terlihat pada keadaan jalan, yang mengalami rusak parah, dengan jalan yang dilewati beberapa mobil angkutan karet yang bermuatan berat kurang lebih muatan 50 ton, membuat jalan rusak, bergelombang, berlubang dan sangat licin apabila hujan serta berdebu apabila panas. keadaan tersebut sangatlah membuat masyarakat merasa resah akan kesehatan, dan kenyamanan jalan apabila melewati jalan tersebut. Sebenarnya masyarakat telah mengajukan permohonan kepada PT Perkebunan Karet Unit Usah Padang Pelawi untuk perbaikan jalan yang telah rusak karena tidak mampu menahan beban yang berat lebih kurang setiap harinya namun dari pihak PT perkebunan karet (Persero) tersebut 
hanya memberikan bantuan seperti portal jalan.

\section{f). Dari Segi Keagamaan}

Dari hasil pelaksanaan dilapangan terlihat bahwa program yang dilakukan oleh PT Perkebunan Karet (Persero) sudak cukup baik atau memiliki tanggung jawab sosial perusahaan sebagaiman mestinya dengan didirikannya sarana dan prasarana ibadah, serta kegiatan-kegiatan kerohanian yang mendukung, seperti disaat bulan Ramadan dilaksanakannya santunan kepada anak-anak yatim/piatu, buka bersama untuk masyarakat dilingkup perusahaan, acara robana, kasida bahkan diisi dengan pengajian untuk ibu-ibu ikii ( Ikatan Keluarga Ibu-ibu) setiap hari jumat sore.

\section{g). Dari Segi Pelestarian Lingkungan}

PT Perkebunan Karet Unit Usaha Padang Pelawi telah melaksanakan program pelestarian lingkungan sepertimelakukan penghijauan kembali pada lahan kritis seperti penanaman bibit karet stekulasi, mengganti pohon tebangan dengan bibit siap pindah tanam, penghijauan badan jalan seluma dengan memberikan bibit tanaman pohon lindung, lomba kampung bersih yang dilakukan oleh kampung lawang agung dan sidu luhur, bantuan bibit kayu desa padang pelawi, serta melakukan kegiatan bersih-bersih perkarangan rumah warga masingmasing pada saat hari libur kerja.

Dari hasil pelaksanaan dilapangan terlihat bahwa program yang dilakukan oleh PT Perkebunan Karet (Persero) dari segi pelestarian lingkungan sudak cukup baik atau memiliki tanggung jawab sosial perusahaan sebagaimana mestinya dengan memperhatikan lahan-lahan kritis yang memang harus ditanam oleh bibit-bibit tanaman lindung, bibit karet dan sebagainya. Namun seperti yang telah dibahas pada program kesehatan, masalah limbah pabrik yang harus lebih diperdulikan oleh pihak PT Perkebunan Karet (Persero) karena sangat mengganggu hidup dan kehidupan masyarakat setempat.

Berdasarkan hasil wawancara penulis dengan beberapa narasumber diantaranya:

a). Manajemen PTPN (persero) bagian TJSP ( Tanggung Jawab Sosial 
Tanggung Jawab Sosial Perusahaan yang Dilakukan oleh PTPN VII

Di Kecamatan Sukaraja Kabupaten Seluma

Perusahaan unit usaha padang pelawi) Pak DIANTO KAUSEL,NIK 1705010508690001, Pak RATIMI atasan ${ }^{10}$

- Apa saja Progaram tentang tanggung jawab sosial perusahaan yang telah diberikan oleh PTPN VII Unit Usaha Padang Pelawi ini ?

Bahwa dengan hasil wawancara menyatakan bahwa ada beberapa program yang telah dilaksanakan seperti program peduli mitra (PKBL) yang dilakukan dari sekian masyarakat desa sekitar perusahaan, dengan mendata sesuai KTP (kartu tanda penduduk) sekitar perusahaan, berupa bantuan dana yang diberikan sebagai usaha langsung dari masyarakat itu sendiri, namun ada juga yang meliputi program tanggung jawab perusahaan yang telah dilaksanakan seperti dari segi kedermawanan (bantuan kepada anak-anak yatim/piatu, bantuan makan tambahan BMT-SD, bantuan korban

\footnotetext{
${ }^{10}$ Wawancara terhadap manajemen PTPN VII padang pelawi terkhusus untuk bagian TJSP. Dianto kausel.tempat PTPN unit usaha padang pelawi.tanggal 15 april 2015.pukul 08.30

Wawancara bagian umum PTPN VII Unit Usaha Padang Pelawi.Ratimi.tempat PTPN Unit Usaha padang pelawi.tanggal 15 april 2015.pukul 10.00
}

bencana alam, bantuan orang-orang cacat yang terkhusus untuk karyawan PT Perkebunan Karet, dari segi pendidikan seperti pemberian beasiswa terhadap anak-anak yang berprestasi dari SD s/d SLTA untuk rangking 1 dan 2 terkhusus untuk anak-anak karyawan gol 1A s/d 1D PT Perkebunan Karet (Persero), dari segi kesehatan (memberikan pelayanan kesehatan gratis dalam bentuk pengobatan puskesbun di lingkungan perusahaan PT Perkebunan Karet BPJS, namun apabila sakit tidak dapat ditangani di lingkup puskebun perusahaan maka akan diberikan rujukan melalui distrik s/d Rumah Sakit di kota Bengkulu seperti M.Yunus, dan Rumah sakit DKT, pelayanan pengobatan tersebut yang diberikan oleh PT Perkebunan Karet meliputi untuk karyawan bulanan, sadapan, teknik dan pabrik, pengobatan yang diberikan hanya dapat dirasakan oleh karyawan-karyawan, staf perusahaan perkebunan karet tersebut dan tidak dapat di berikan kepada masyarakat luar perusahaan yang tidak bekerja tetap di PT Perkebunan karet), dari segi pembanguan (perusahaan telah 
meberikan sarana lapangan olah raga, gedung serba guna, masjid, lapang sekolah, pembangunan pos jaga, pembangunan paud, TK, pembangunan gereja, TPQ, dan lain sebagainya dengan dana yang diberikan sesuai dengan pembangunan ataupun hanya sekedar dana perehaban, dari segi keagamaan

(perusahaan menyediakan sarana prasarana ibadah, melaksanakan kegiatankegiatan kerohanian, seperti memberikan santunan anak yatim/piatu, pengajian, buka dibulan Ramadan, safari Ramadan, dan lain sebagainya, dari segi pelestarian lingkungan, (seperti kebersihan lingkungan disaat hari libur ole PT perkebunan Karet, Penanaman lahan kritis, melakukan stekulasi bibit karet, melakukan penghijauan badan jalan dan lain sebagainya.

b). Staf-Staf / karyawan

- Apa saja yang telah diberikan oleh Perusahaan Karet ini terhadap karyawan-karyawan pekerja perkebunan karet dan masyarakat diluar group serta apa saja yang bapak lakukan sebagai bagian dari karyawan perusahaan karet ini demi memberikan tanggung jawab sosial perusahaan kepada lingkungan sekitar ?

Mabes (.Mandor Besar) Pak Buadi (menyatakan bahwa perusahaan melakukan penebanngan pada lahan karet yang sudah harus untuk diganti dan melaksanakan penanaman kembali sekitar usia 4 tahun setengah maka siap sadap merupakan proses pembibitan tanaman karet yang sudah terbilang cepat dilapangan dengan melakukan perekrutan karyawan pekerja sadapan, mendapatkan bantuan dibidang kesehatan seperti bantuan pengobatan gratis BPJS, dibidang lingkungan pemerintah telah mengeluarkan AMDAL dari segi dampak air, tanah, udara yang terbilang aman, tidak didirikannya sekolah diluar perusahaan, dapat menggunakan TPQ, lapangan bola kaki, gedung serba guna apabila masyarakat melampirkan permohonan, adanya perekrutan terhadap karyawan sekitar perusahaan yang ingin bekerja di perusahaan Perkebunan 
Tanggung Jawab Sosial Perusahaan yang Dilakukan oleh PTPN VII

Di Kecamatan Sukaraja Kabupaten Seluma

Karet ${ }^{11}$.Hampir setiap harinya pabrik melakukan pengekpor karet berkisar 50 ton ke pulau bai sebagai jalur perairan

Berkisar beberapa angkutan yang digunakan sebagai pengangkut karet pengolahan pabrik. ${ }^{12}$ Sehingga dapat memberikan sedikit banyaknya bantuan kepada lingkungan sekitar perusahaan baik untuk karyawan-karyawan perkebunan sendiri maupun untuk masyarakat sekitar perusahaan.Harian lepas

(melaksanakan kerja seperti pembibitan, melakukan stekulasi, kebersihan dibawah pohon agar tidak terjadi kebakaran dan lain sebagainya dengan upah yang dibayar sesuai dengai kerja harian ${ }^{13}$. c). Masyarakat Umum diluar group perusahaan $^{14}$

- Apa dampak ngatif masalah lingkungan yang dirasakan

${ }^{11}$ Wawancara bagian mandor besar (mabes) PTPN VII Unit Usaha Padang Pelawi.Buadi.tempat PTPN VII unit usaha padang pelawi. Tanggal 18 april 2015.pukul 9.30

${ }^{12}$ Wawancara bagian keamanan PTPN VII Unit Usaha Padang Pelawi. Devi.tempat PTPN VII padang pelawi.tanggal 20april2015.pukul 10.00

${ }^{13}$ Wawancara bagian harian lepas.tempat PTPN VII Unit Usaha Padang Pelawi. Tanggal 20 april 2015.pukul 11.27

${ }^{14}$ Wawancara masyarakat umum. Desa niur.hudin.tanggal22 april 2015.pukul 14.30 selama ini akibat pengolahan pabrik.

udara dari pabrik yang setiap pagi menggangu pernapasan yang dihirup membuat masyarakat sekitar merasa terganggu.

d). Masyarakat yang mendapatkan bantuan pemberian dana PKBL

- Dalam bentuk bantuan seperti apa yang diberikan dalam program PKBL

Bantuan proposal dan sebaginya (cukup dapat merasakan bantuan dari segi sosial yang dilakukan secara langsung atas bantuan dana yang diberikan.

e). kepala desa niur, siabun, padang pelawi. ${ }^{15}$

- Apa saja dampak yang dirasakan oleh masyarakat sekitar perusahaan terhadap Perusahaan perseroan Terbatas Perkebunan Nusantara VII kecamatan sukaraja kabupaten seluma

1). Hampir setiap pagi masyarakat sekitar merasakan keadaan lingkungan yang cukup memprihatinkan, udara yang terdapat didalam pabrik pengolahan karet berhembus di

\footnotetext{
${ }^{15}$ Wawancara Kepala desa niur, burhan.tanggal 23 april 2015.pukul 15.30
} 
pemukiman warga sehingga masyarakat merasa udara yang mereka hirup sangat tidak baik atau tidak sehat, sangat mengganggu sistem pernapasa.

2). Aapabila terdapat dampak yang cukup segnipikan terhadap udara yang kotor atau tidak sehat dari pabrik pengolahan karet tersebut maka tidak adanya kepedulian dari PT untuk membantu berobat kerumah sakit terdekat , masyarakat berobat dengan dana yang dimiliki secara pribadi berarti tanpa bantuan dari perusahaan tersebut padahal dampak yang mereka rasakan tersebut dari pabrik pengolahan karet perusahaan peroprasi.

3). Pembuangan limbah yang dilakukan oleh PT Perkebunan Karet tersebut jatuh mengikuti aliran air di sungai andalas, sungai yang dimiliki oleh masyarakat disekitar perusahaan, sudah hampir sejak lama masyarakat disekitar menggunakan air tersebut terutama diwaktu terjadinya kekeringan/kemarau masyarakat sering mandi ataupun mengambil air untuk bahan pangan, namun setelah terjadi pembuangan limbah disungai tersebut atas aliran bendungan air limbah di PT Perkebunan Karet tersebut masyarakat takut untuk menggunakan air tersebut, mandi saja mereka takut apalagi harus mengkonsumsinya, padahal kalanya sungai tersebut sangat berguna untuk kehidupan masyarakat

4). Pembuangan limbah pabrik di sungai andalas merupakan aliran keberlanjutan di sungai jenggalu yang merupakan bahan PDAM kota Bengkulu.air yang diolah dikonsumsi oleh mayarakat kota Bengkulu sedangkan masyarakat pemilik sungai tersebut tidak sedikit pun merasakan manfaat air yang mereka miliki sejak terjadinya pencemaran limbah disungai andalas

5).Jalan yang rusak karena angkutan yang berat dari pabrik pengolahan karet membawa karet melewati jalan penduduk. 
Tanggung Jawab Sosial Perusahaan yang Dilakukan oleh PTPN VII

Di Kecamatan Sukaraja Kabupaten Seluma

6). Kurang kepedulian atau sosialisasi anatara PTPN unit usaha padang pelawi dengan masyarakat disekitarnya sehingga penduduk merasa perusahaan tersebut tidak dapat mengindahkan keinginan mereka

7). Meminta bantuan perbaikan jalan namun hanya diberi portal jalan.

8). Bahwasahnya masyarakat sekitar perusahaan pernah melakukan tuntutan secara class action/ perwakilan untuk membela hak tanah ulayat dan adat namun pemerintah tidak mengindahkannya.

9). Terjadinya longsor atau erosi dibadan sungai andalas membuat perkebunan sawit warga menjadi tumbang jatuh kesungai

10).Dana bantuan yang diberikan perusahaan hanya berkisar 500,000 (lima ratus ribu rupiah ) paling besar

11).Fakta yang terjadi dilapangan pemerintah selalu berdalih menyatakan bahwa telah dilakukannya antisipasi air, udara dan tanah dengan alhasil yang baik / tidak akan memberikan dampak yang negatif bagi masyarakat sekitarnya apabila masyarakat menyatakan protes kepada perusahaan akan dampak yang dirasakan beda dengan apa yang sebenar-benarnya dirasakan oleh masyarakat disekitar perusahaan, mereka bahkan sangat terganggu akan dampak yang diberikan pabrik.

12).Dari segi kesehatan masyarakat tidak mendapatkan bantuan yang baik, atau memadai seperti tidak adanya puskesmas umum yang didirikan untuk berobat, atau klinik sekali pun .

13).Pendidikan yang kurang untuk masyarakat diluar group perusahaan, seperti tidak mendapatkan bantuan beasiswa bagi anak-anak yang kurang mampu.

Akibat keadaan tersebut warga merasa sangat terganggu dengan hidup dan kehidupannya.maka masyarakat sekitar perusahaan meminta sedikit uluran, kepedulian 
Perusahaan perkebunan karet tersebut lebih sedikit memperhatikan keadaan mereka.

f). Anak karyawan ( Dian,danna) ${ }^{16}$

- Apa yang diberikan oleh perusahaan dibidang pendidikan, kesehatan terhadap karyawan setempat dan masyarakat luar group

1)Hasil

wawancara mengungkapkan bahwa tidak adanya pembangunan sekolah SD s/d SLTA kecuali PAUD dan TK (Taman Kanakkanak) itu pun hanya untuk anak-anak karyawankaryawan, staf.

2)Untuk anak karyawan SD s/d SLTA yang bersekolah di lingkuan desa perusahaan mendapatkan angkutan mobil sebagai antar jemput pulang sekolah.

3)Mendapatkan tunjangan keluarga apabila belum menikah, dari segi

\footnotetext{
${ }^{16}$ Wawancara anak karyawan Mabes PTPN VII Unit Usaha Padang Pelawi.Dian.tanggal 24 april 2015.pukul 14.28

Wawancara anak karyawan mabes PTPN VII Unit Usaha Padang Pelawi.Danna.tanggal 24 april 2015.pukul 15.00
}

pendidikan, kesehatan dan lain sebagainya namun apabila sudah menikah tidak akan mendapakan tunjangan lagi begitu pula apabila sudah pensiun kerja maka semua akan diputus kecuali mereka menjadi pegawai baru dari keluarga nya yang telah pensiun .

Dengan Impormasi yang saya dapat tentang tanggung jawab sosial yang diberikan oleh Perseroan Terbatas perkebunan Karet Unit Usaha Padang Pelawi dengan melihat data-data yang diberikan seperti

a). Data dokumen operasional programprogram yang ada di PT Perkebunan Karet Unit Usaha Padang pelawi dengan ditunjang beberapa gambar, seperti dibidang pendidikan, kesehatan, keagamaan, olahraga, dan sebagainya.

b). Data laporan-laporan triwulan maupun tahunan terhadap pencapaian tujuan-tujuan program sesuai dengan aturan yang termuat pada Peraturan Daerah nomor 1 tahun 2014.

c). Gambar-gambar bangunan yang menunjang program tanggung 
jawab sosial perusahaan seperti, tempat ibadah umat islam, taman kanak-kanak, paud, kesehatan, lapangan bola kaki, gedung pertemuan, dan lain-lain.

d). Ungkapan perasaan yang dirasakan masyarakat di lingkungan perusahaan, sebagai bahan perbandingan antara inpormasi yang diberikan oleh perusahaan, dengan masyarakat sekitar perusahaan.

Faktor-faktor yang menjadi pendukung program Perseroan Terbatas Perkebunan Nusantara VII unit Usaha Padang Pelawi adalah $^{17}$

a) Perusahaan memiliki dasar undang-undang dan peraturan dalam pembuatan dokumen operasional program sesuai dengan Tanggung Jawab Sosial Perusahaan.

b) Perusahaan memiliki dokumen pelaksanaan program visi, misi, tujuan dan strategi yang jelas mengenai Perusahaan

c) Perusahaan memiliki Unit khusus yang menangani masalah Tanggung Jawab Sosial Perusahaan atau CSR terhadap

\footnotetext{
${ }^{17}$ Wawancara bagian umum PTPN Unit Usaha padang
} pelawi.Ratimi.tanggal 15april2015.pukul 08.30 peningkatan kualitas dan kemampuan petugas TJSP ( tanggung jawab sosial perusahaan)

d) Perusahaan memiliki anggaran untuk kegiatan CSR / Tanggung Jawab Sosial Perusahaan setiap tahun/ triwulannya.

e) Dalam prosesnya perusahaan dapat melibatkan masyarakat penerima bantuan program dan tokoh masyarakat sekitar perusahaan

f) Bantuan yang diberikan perusahaan sesuai dengan yang diinginkan penerima bantuan program karena adanya komunikasi yang baik mengenai bantuan yang akan diberikan

\section{Bentuk sanksi yang diberikan apabila} tanggung jawab sosial perusahan PTPN VII Kabupaten seluma tidak dilaksanakan.

\section{Pasal 90 UU BUMN}

"BUMN dalam batas kepatutan hanya dapat memberikan donasi untuk amal atau tujuan sosial sesuai dengan ketentuan peraturan perundangundangan".

Dalam Undang-Undang Nomor 19 Tahun 2003 Tentang Badan Usahan Milik Negara diatur juga beberapa hal yang dapat dikaitkan dengan CSR, yaitu 
terdapat pada Pasal 2 Ayat (1), dimana ditentukan bahwa, maksud dan tujuan pendirian BUMN adalah:

a) Memberikan sumbangan bagi perkembangan perekonomian nasional pada umumnya dan penerimaan negara pada khususnya;

b) Mengejar keuntungan;

c) Menyelenggarakan kemanfaatan umum berupa penyediaan barang dan/atau jasa yang bermutu tinggi dan memadai bagi pemenuhan hajat hidup orang banyak;

d) Menjadi perintis kegiatan-kegiatan usaha yang belum dapat dilaksanakan oleh sektor swasta dan koperasi;

e) Turut aktif memberikan bimbingan dan bantuan kepada pengusaha golongan ekonomi lemah, koperasi, dan masyarakat.

\section{Undang-Undang Nomor 25 Tahun 2007 Tentang Penanaman Modal}

\section{Undang-Undang Nomor 32}

tahun2009 Tentang Perlindungan dan Pengelolaan Lingkungan hidup

Perwujudan untuk pemenuhan hak atas lingkungan hidup yaitu dengan munculnya Undang-Undang Nomor 4 Tahun 1982 tentang Ketentuan Pokok Pengelolaan Lingkungan Hidup yang telah diubah dengan Undang-Undang Nomor 23 .Tahun 1997 tentang Pengelolaan Lingkungan Hidup (UUPLH) dan kemudian diubah lagi menjadi nomor 32 tahun 2009 tentang Perlindungan dan Pengelolaan Lingkungan Hidup.

Berdasarkan uraian diatas kepastian hukum bagi perusahaan untuk melaksanakan CSR telah secara jelas diatur dalam peraturan perundang undangan diatas.

\section{Maka sanksi dapat berupa :}

a). Penjara atau denda atau keduanya

b). Orang yang dilarang untuk menjadi direktur perusahaan dalam jangka yang cukup panjang

c). Orang yang diperlukan untuk mmberikan ganti rugi kepada setiap orang yang telah menderita sebagai hasil dari dampak pelanggaran apapun.

d). Perusahaan ditangguhkan untuk melakukan kegiatan perdagangan atau pertukaran saham.

e). Dalam hal ini terjadi pelanggaran Undang-undang terus-menerus , perusahaan yang ditunjukan untuk berhenti beroprasi dari kegiatan stertentu. 
Tanggung Jawab Sosial Perusahaan yang Dilakukan oleh PTPN VII

Di Kecamatan Sukaraja Kabupaten Seluma

Penerapan CSR pada Negaranegara maju telah menjadi penilaian hukum oleh otoritas dan pasar modal yang dituangkan dalam dalam bentuk Public report, disamping penilaian dari public sendiri. Teryanta perusahaan yang melaksanakan tugasnya atau TJSP dalam aktivitas usahanya akan mendapatkan Reward berupa keuntungan yang memuaskan.

\section{PENUTUP}

Kesimpulan

Prosedur dan Model Pelaksanaan Tanggung Jawab Sosial yang dilakukan oleh Perusahaan PTPN VII di kecamatan Sukaraja kebupaten Seluma

Prosedur dan Model pelaksanaan Tanggung Jawab Sosial Perusahaan PTPN meliputi: Program Kemitraan, Program Kedermawanan, Program Pendidikan, Program Kesehatan, Program Keagamaan, Program Pembangunan, Program Pelestarian Lingkungan.Sedangkan untuk tata cara pelaksanaan tanggung jawab sosial perusahaan tersebut meliputi :

a) Memberikan bantuan dana sebagai modal pengembangan mitra binaan dengan TIM evaluasi kerja yang tersedia dengan melampirkan proposal yang langsung diberikan oleh masyarakat(Program Kemitraan)

b) Memberikan santunan terhadap anak-anak yatim, orang sakit, bantuan korban bencana alam ( Program Kedermawanan)

c) Memberikan bantuan terhadap sekolah disekeliling perusahaan seperti bantuan sarana dan prasarana taman kanak-kanak, paud, dan pembuatan lapangan sekolah dengan melampirkan proposal yang langsung diberikan oleh masyarakat ( Program Pendidikan)

d) Mendirikan Puskesbun dikawasan perkebunan

(Program

\section{Kesehatan)}

e) Mendirikan TPQ, gedung serbaguna dan lain-lain yang dapat digunakan oleh masyarakat ( Program Pembangunan)

f) Memberikan sarana prasarana masjid, atau TPQ seperti Sahjada

\section{( program Keagamaan).}

Sehingga dapat disimpulkan hampir sebagian dari tanggung jawab sosial perusahaan di kecamatan sukaraja kabupaten seluma tidak terlaksanakan secara baik atau efektip terutama 
dibidang pelestarian lingkungan hidup, pendidikan dan kesehatan.

\section{Bentuk sanksi yang diberikan pemerintah apabila tanggung jawab sosial perusahan PTPN VII Kabupaten seluma tidak \\ dilaksanakan.}

Selain itu juga pemerintah telah memberikan peraturan sanksiyang mendukung apabila Program Tanggung Jawab Sosial Perusahaan ini tidak dijalankan secara baik dan optimal.

\section{a) Sanksi Pidana ( Penjara, kurungan, hukum mati)}

b) Sanksi HAN ( Pencabutan izin operasional perusahaan)

\section{c) Sanksi Perdata}

Namun apabila perusahaan yang melaksanakan tugasnya secara baik dalam aktivitas usahanya akan mendapatkan Reward berupa keuntungan yang sangat memuaskan.

\section{Saran}

Seharusnya perusahaan mampu memiliki dokumen tentang pelaksanaa monitoring dan evaluasi yang menjadi dasar bertindak perusahaan untuk mengawasi bantuan yang diberikan , membuat laporan dan memberikan penilaian terhadap keberhasilan program.
Seharusnya perusahaan memiliki Tim Pelaksana Program CSR yang lebih mengetahui dan memahami tentang Prosedur-prosedur CSR agar dapat berjalan secara efektif. Kepedulian PTPN terhadap masyarakat disekitarnya mestinya harus di indahkan, dapat bersosialisasi dengan baik. Dapat Bekerjasama menjaga,merawat, memperbaiki lingkungan secara baik.

\section{DAFTAR PUSTAKA}

\section{Buku}

Asyhadie, Zaeni ,2005,HukumBisnis , PT Raja Grafindo, Mataram.

A.Sonny.1998. Etika Bisnis Tuntutan dan Relevansinya, Kanisius.Yogyakarta.

Endi Robert.2007.Kritik Pengaturan CSR UUPT.Suara Pembaruan.jakarta.

Widjaya Gunawan,2008,Seri Pemahaman Perseroan Terbatas Risiko Hukum \& Bisnis Perusahaan Tanpa CSR,Forum Sahabat.Jakarta.

Harahap Yahya,2009, Hukum Perseroan Terbatas.Sinar Grafika,Jakarta

Hasyim, Farida, 2009. Hukum Dagang.Sinar Grafika,Jakarta. Hermansyah,2005, Hukum Bisnis Untuk Perusahaan, Kencana, Jakarta.

Kansil, Christine, 2005, Hukum Bisnis Untuk perusahaan, Kencana,Jakarta.

Kasali Rhenaldy .2003. Manajemen Public Relations.Grafiti.Jakarta.

R.Abdul.2005.Hukum Bisnis Untuk Perusahaan teori dan contoh kasus ,Kencana, Jakarta. 
Tanggung Jawab Sosial Perusahaan yang Dilakukan oleh PTPN VII

Di Kecamatan Sukaraja Kabupaten Seluma

Suharto Edi,2009. Pekerjaan Sosial di Dunia Industri,Memperkuat CSR. Alfabeta.Bandung.

Solihin Ismail,2008. Corporate Social Responsibility From Charity to Sustainability, PT Riau Andalan Pulp and Paper,Jakarta.

Soekanto Serjono,2005. Pengantar Penelitian Hukum Universitas Indonesia Grafindo.Jakarta

Sugiyono.2014. Metode Penelitian Kuantitatif Kualitatif dan $R \& D$.Alfabeta, Bandung

Zaim Saidi.2004. Menjadi Bangsa Pemurah Wacana dan Praktek Kedermawanan Sosial di indonsia.Piramida.Jakarta

\section{Peraturan Perundang-undangan}

Undang-Undang Perseroan Terbatas No 40 tahun 2007

Peraturan Daerah No 1 tahun 2014 tentang Tanggung Jawab Sosial Perusahaan.

Undang-undang No 8 tahun 1995 tentang Penanaman modal.

Undang-undang No.40 tahun 2007 tentang Tanggung jawab Sosial dan lingkungannya.

Pasal 25(b)Peraturan Pemerintah, tentang Penanaman Modal.

Pernyataan Ketua Panitia Khusus UU PT Akil Mochtar

Pasal 67-69(ayat 1) UUPPLH

\section{Internet/Karya Ilmiah}

Arif Muhammad,2007.Implementasi GCG melalui CSR.diakses melalui Muhariefeffendi. wordpress.com tanggal 1 April 2015,pukul $15 ; 24 \mathrm{Wib}$

"Corporate social responsibilty,Tanggung jawab sosial atau Strategi perusahaan"melalui http://www.alt-jurnalCSR.com, diakses tanggal 11 maret 2015,Pukul 13.50wib.

Metode Penelitian",melalui http://www.MetodePenelitian.c om, diakses tanggal 13 maret 2015 Pukul 13.00

Muhammad Arif Effendi.2007. Implementasi GCG melalui CSR.diakses melalui Muhariefeffendi.wordpress.com tanggal 1 April 2015,pukul 15;24 Wib

"Perseroan Terbatas Perkebunan Nusantara VII",melalui http://WWW.PTPNVII.com,diaks es tanggal 10 maret 2015 Pukul 13.12 .

Pengaruh PengungkapCsr terhadap nilai perusahan dengan proitabilitas sebagai variable pemderasi" melalui http://www.alt-jurnalFE.com, diakses tanggal 11 maret 2015,Pukul 14.00.

Perkebunan Nusantara " melaluihttp://www.PengertianP erkebunanNusantara VII.com,diaksestanggal 30 april 2015, pukul 13.20

Pernyataan Ketua Panitia Khusus UU PT Akil Mochtar

Wikipedia"Perkebunan Nusantara VII",melalui http://WWW.PTPNVII.com,diaks es tanggal 10 maret 2015 Pukul 12.30 . 